\title{
Effects of Marshes on Water Quality
}

\author{
G. FRED LEE ${ }^{1}$, EUGENE BENTLEY, and ROHEL AMUNDSON
}

Marshes and other wetlands in which there is a profuse growth of aquatic plants are common in many parts of the world. Wisconsin contains many thousands of hectares of marsh vegetation, which typically stands from a half meter to several meters above the normal water elevation during the growing season. Water depths range from a few centimeters to several meters.

There is a certain flux of nutrients to the marsh from groundwaters, surface flow, and direct precipitation and gas exchange. The outflow is manifest in deposition of materials in the sediments, gas exchange, and transport in streams draining the marsh. The marsh is a complex hydrologic, chemical, and biochemical system which can transform various elements into compounds that may improve water quality or have a deleterious effect.

Wetlands are often considered low-value land since in their normal condition they cannot be used for most agricultural activities or urban development. There has been increasing pressure to drain marshes to provide higher-value land for suburban development. Also, some farmers have capitalized on the large amounts of nutrients stored within the marsh to develop muck farming after draining the marsh. The drainage of a marsh changes the release of aquatic plant nutrients. This chapter discusses results from the University of Wisconsin Water Chemistry Program on effects of marshes on water quality. Data on the chemical composition of waters discharged from several Wisconsin marshes as well as studies on the leaching of aquatic plant nutrients from drained marshes are primarily the result of studies by Bentley (1969) and Amundson (1970). Both of these students' theses should be consulted for additional details.

\section{Wisconsin Study Areas}

A several-year study on four marsh areas located near Madison, Wisconsin, illustrates general conclusions on the effects of marshes on water quality.

${ }^{1}$ Current affiliation: G. Fred Lee \& Associates, El Macero, CA, gfredlee@aol.com, http://www.gfredlee.com 
One study area was Waunakee Marsh in Dane County, maintained by the State of Wisconsin as a public hunting ground, wildlife habitat, and northern pike spawning area. This marsh comprises some 392 ha. Its source of water is mainly groundwater discharged through numerous springs found throughout the marsh. A channel has been dredged through the marsh from an adjacent marsh area to the northwest, which during periods of heavy rainfall becomes an important source of water for the marsh. Runoff from adjacent agricultural lands, primarily growing corn, provides additional water and chemical input during periods of heavy rainfall and snow melt. Waters discharged from Waunakee Marsh are the head waters of Six Mile Creek, which eventually empties into Lake Mendota (Fig. 1). The data presented in this chapter will be restricted to the samples taken at the discharge from this marsh to Six Mile Creek.

Horicon Marsh, another major study area, is located in Dodge and Fond du Lac counties in Wisconsin. This marsh is $23 \mathrm{~km}$ in length and 5-6 km wide and contains approximately 12,000 ha. Figure 2 shows a map of the Horicon Marsh sampling stations. Two-thirds of this marsh is controlled as a wildlife refuge by the U.S. government, primarily for geese. The remaining 4000 ha are owned by the State of Wisconsin and are maintained for the same purposes. Three branches of the Rock River are major sources of water entering the marsh. The south and west branches combine to flow through the upper two-thirds of the marsh. The east branch flows through the lower one-third of the marsh and combines with water from the upper two-thirds before flowing through the city

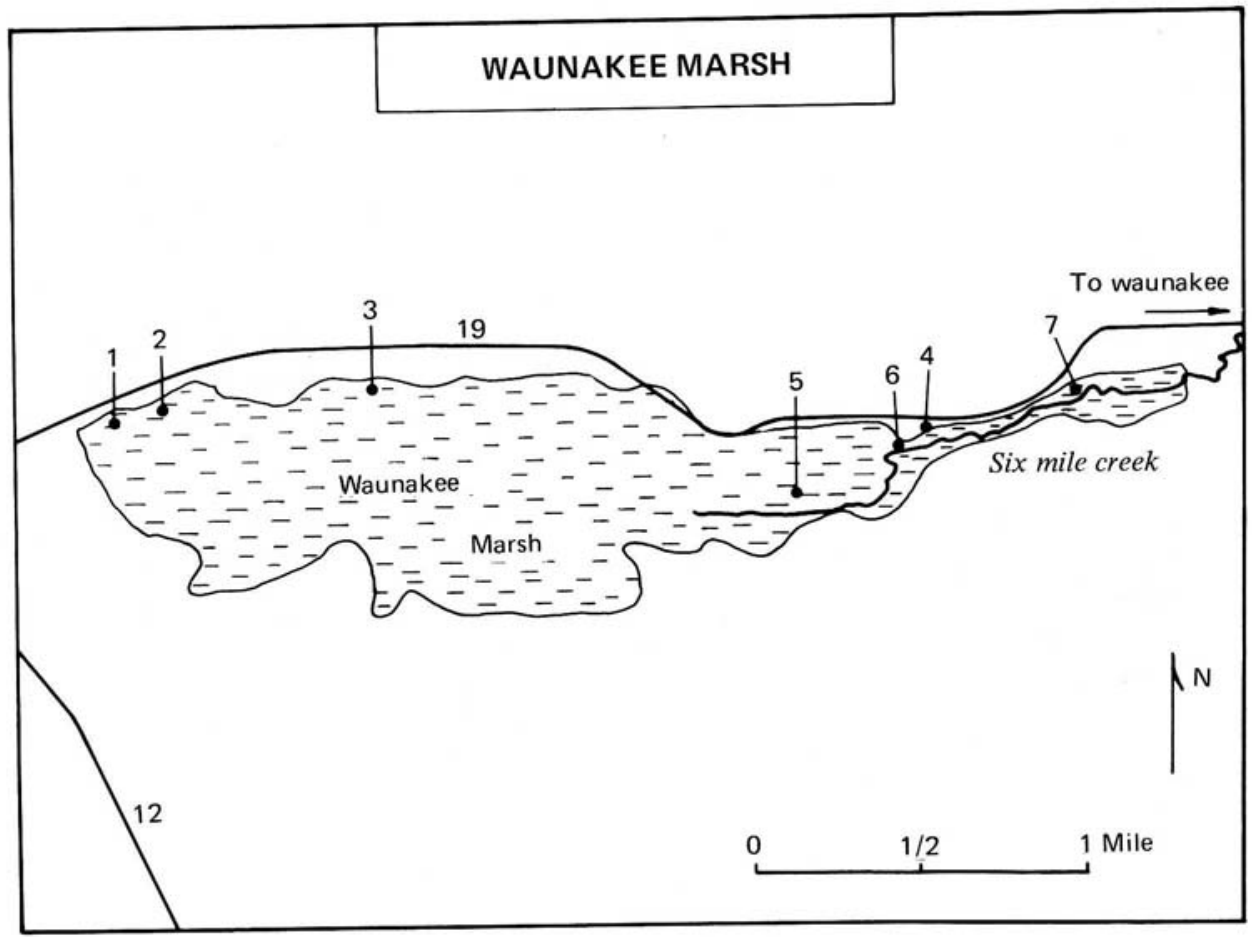

Fig. 1. Waunakee Marsh sampling stations. 


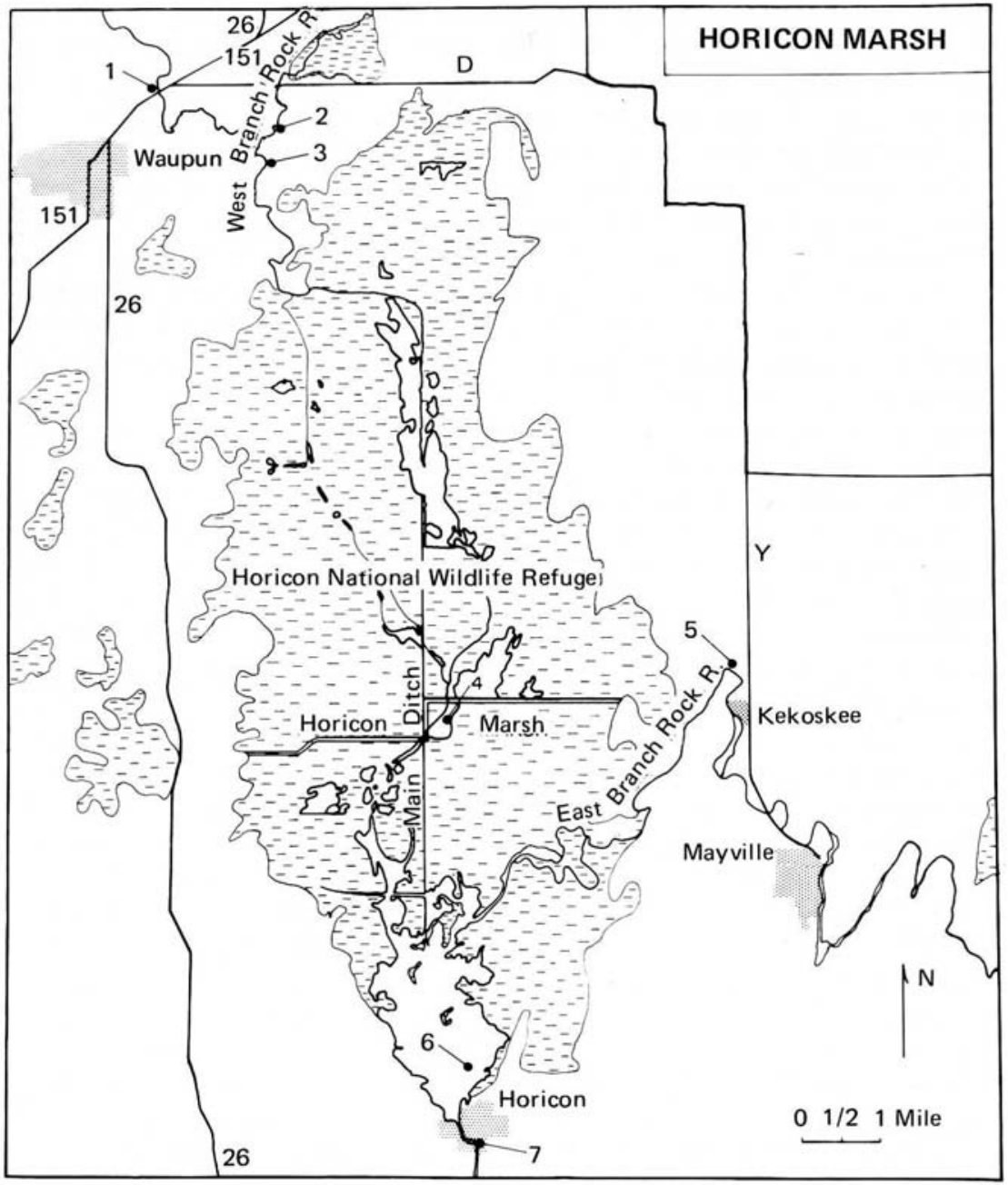

Fig. 2. Horicon Marsh sampling stations.

of Horicon and over the State of Wisconsin Department of Natural Resources' dam. This dam, the outlet of this marsh, was the sampling site for the data presented. Land surrounding Horicon Marsh is primarily agricultural. Above Horicon Marsh there are numerous cheese factories, vegetable-canning companies, creameries, and domestic waste-water treatment plants which discharge their waste to tributaries to the marsh. The agricultural lands and industrial and municipal wastes have a significant effect on the total chemical input. There are significant inputs from direct precipitation on the surfacewater and groundwater inflow.

The third area was Shakey Marsh, in Dodge County, Wisconsin, approximately $10 \mathrm{~km}$ southeast of Randolph, Wisconsin. A substantial part of this marsh has been underlain with a tile drainage system, which was installed for the purpose of utilizing the marsh for agricultural lands. At the time of the 
original sampling of Shakey Marsh approximately 64 ha were under cultivation for carrots and onions. Another 24 ha had been tiled and drained but not cultivated. Samples from Shakey Marsh included soil samples taken in both the cultivated and uncultivated areas as well as periodic sampling of the discharge of the tile fields from each of these areas. The Shakey Marsh studies provide an opportunity to compare the chemical composition of water from recently drained marshes such as Shakey, as compared to the existing marshes of Waunakee and Horicon.

The fourth study area, Cambra Creek, is a marsh area that discharges into Fox Lake, in Dodge County, Wisconsin. This marsh area had been drained the year prior to initiation of the sampling program as part of a fish-management program by the Department of Natural Resources. At the time of sampling the marsh had been refilled with water to its normal level. Studies on Cambra Marsh as well as the majority of the data on all the other study sites will be published elsewhere. The complete data are available for review in the thesis by Bentley (1969). He also describes field sampling and laboratory analysis procedures which were in accord with normal limnological-water chemistry techniques.

We hoped it would be possible to make quantitative estimates of the effect of marshes on water quality, in particular, to be able to make mass-balance computations on the amount of chemicals transported through the marsh from various sources, the transformations that take place in the marsh, and the amount that is transported out of it. This was not possible because of the extremely complex hydrology of the marsh system. It is possible to gauge inflow and outflow from a marsh, but extremely difficult, if not impossible, to make accurate estimates of groundwater inflow and evaporation within the marsh. Changes in composition between inflow and outflow of surface waters may reflect some changes in the composition due to evaporation or to the input of materials from groundwaters. The groundwater input to some marshes is extremely high; one of the reasons a marsh exists is because it is a discharge area for groundwater. Because of inadequate funding to do a complete hydrologic study on each marsh, it is necessary to interpret results in a qualitative way rather than in the strict quantitative fashion. However, even with this limitation a reasonable estimate can be obtained of the effects of marshes of the type being investigated on water quality.

Productivity. The most striking characteristic of a marsh is the large amount of photosynthesis within the system by macrophytes, epiphytes, and benthic algae. Photosynthetic activity and the accompanying respiration of the aquatic plant and bacteria present within the system lead to certain types of changes. The most obvious of these is the diurnal variation of dissolved oxygen and concomitant variations in $\mathrm{pH}$. Typical values for the diurnal variation of dissolved oxygen in the outlet of Waunakee Marsh are shown in Fig. 3: over a 24-hr period, dissolved oxygen ranged from approximately 6 to $9.5 \mathrm{mg} /$ liter; $\mathrm{pH}$ changed from approximately 7 to slightly over 7.2 ; temperature showed the typical diurnal variation expected of shallow waters at this time of year $\left(6-12^{\circ} \mathrm{C}\right)$; other chemical parameters, such as calcium, magnesium, alkalinity, and specific conductance, did not show a consistent trend during this period of time. Studies during August at this location have shown diurnal variations in 


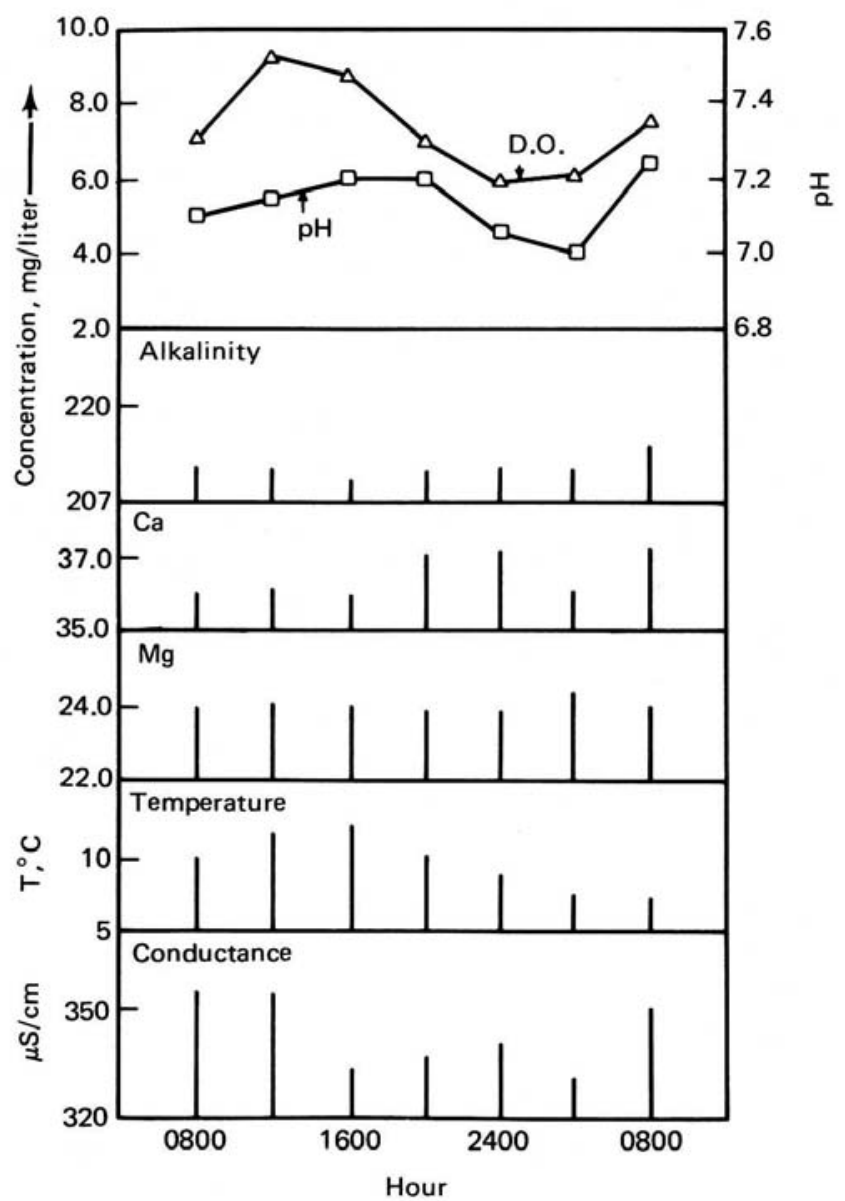

Fig. 3. Diurnal variations in dissolved oxygen, $\mathrm{pH}$, temperature, alkalinity, calcium, magnesium, specific conductance, Waunakee Marsh outlets, May 4, 1968.

dissolved oxygen that range from zero in the early morning hours to in excess of $8 \mathrm{mg} /$ liter in late afternoon.

Chemical Concentrations. Typical data for the concentration of various chemical parameters in the outlet of the Waunakee Marsh over the period October 1967 to November 1968 are shown in Table 1. In January and February of that year the outlet of the marsh was completely frozen and there was no water discharge from it. Over this 1-year period samples taken at approximately monthly intervals had a $\mathrm{pH}$ range from approximately 7.25 to 7.55 and specific conductance ranged from 312 to over $480 \mu \mathrm{s} / \mathrm{cm}$ corrected to $20^{\circ} \mathrm{C}$. Marked variations were noted in the nonfilterable color present in the samples with some of the 12 samples having color values in excess of 100 chloroplatinate units. The high color in both 1967 and 1968 was associated with the breakdown of plant materials at the end of the growing season in the fall of each year, a period of low flow from the marsh. The sodium, potassium, calcium, and 


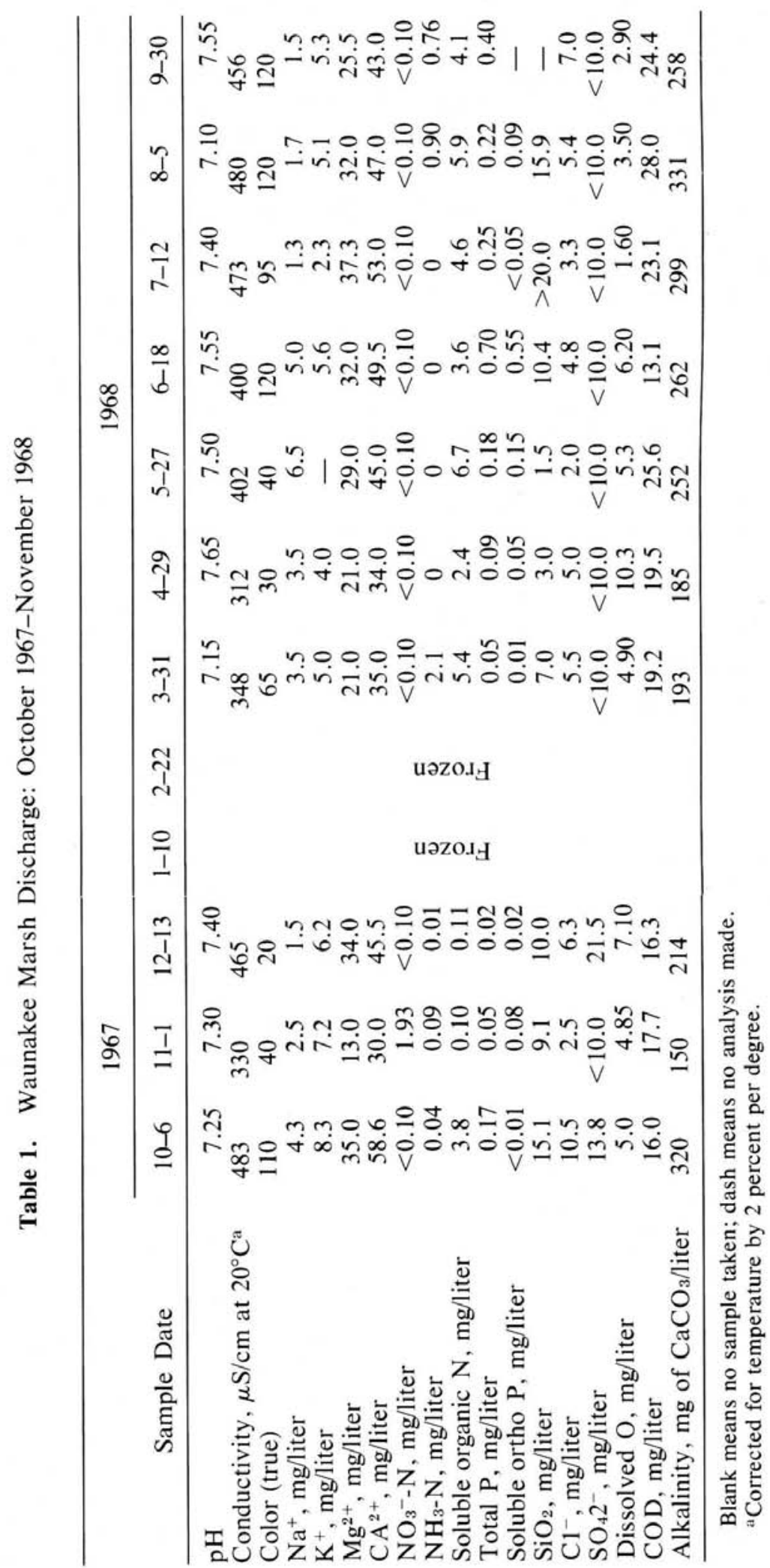


magnesium data for the outlet of Waunakee Marsh are typical of waters of this region of Wisconsin, with the calcium and magnesium data reflecting the photosynthetic precipitation of calcium carbonate, which will be discussed subsequently. The nitrate data show that all the values are less than $0.1 \mathrm{mg} / \mathrm{liter}$ of nitrate nitrogen, with the exception of November 1, 1967. The other samples show that the springs and groundwaters entering this marsh often contain several $\mathrm{mg} /$ liter of nitrate nitrogen. The fact that the outlet of the marsh has little or no nitrate may be related to denitrification reactions.

Table 1 shows that ammonia is extremely low, less than $0.1 \mathrm{mg} /$ liter, except at the time of spring thaw (March 31, 1968), when several mg/liter of ammonium $\mathrm{N}$ were found. Other studies have shown that the denitrification reactions result in the production of nitrogen gas. The soluble organic nitrogen content of the discharge water ranged from a few tenths of $1 \mathrm{mg} /$ liter to several $\mathrm{mg} /$ liter, with values of 2-4 being common. Organic nitrogen data primarily reflect the amounts of particulate organic $\mathrm{N}$ present in the samples. The soluble orthophosphate and total phosphorus for the Waunakee discharge typically showed several hundredths of $1 \mathrm{mg} /$ liter of soluble orthophosphate, with occasional values up in the tenths of $1-\mathrm{mg} /$ liter level. The high values are almost always coincident with periods of high discharge, showing that significant leaching of orthophosphate occurs during periods of time when there are large amounts of flow passing through the marsh. Waunakee Marsh is contributing large amounts of aquatic nutrients (nitrogen and phosphorus) in available forms which could contribute to excessive growths of algae in receiving waters.

The chloride and sulfate data are typical of concentrations normally found for waters in this part of Wisconsin: chloride from 2 to $10 \mathrm{mg} /$ liter, sulfate usually less than $10 \mathrm{mg} /$ liter. The dissolved oxygen data throughout the annual period almost always show 50 percent saturation or less. The few exceptions to this would be the April 29, 1968, data, where the water begins to approach saturation. Some extremely low dissolved-oxygen values are noted during summer; for example, on July 12, 1968, dissolved oxygen was $1.6 \mathrm{mg} /$ liter during late morning. These relatively low dissolved-oxygen values noted in the discharge of the marsh reflect the intensity of respiration reactions of the bacteria present in the marsh, utilizing the plant debris and soluble organic matter released from the macrophytes and attached algae.

The alkalinity data presented in Table 1 reflect the changes due to photosynthetic precipitation of calcium carbonate and the dilution of the groundwater by surface-water flow.

For the Horicon Marsh discharge, Fig. 4 presents the results of the monthly sampling for calcium, magnesium, alkalinity, and specific conductance. Figure 4 shows a marked increase in the calcium, magnesium and alkalinity data during winter, especially under ice cover during January and February 1967. Coincident with ice-out for the marsh in early March there was a major decrease in the concentration of calcium, magnesium, alkalinity, and specific conductance. This decrease was associated with an increase in $\mathrm{pH}$. Dissolved oxygen, sulfide, and other chemical parameters taken at the same time show that in January and February 1967 the outlets of Horicon Marsh had zero 


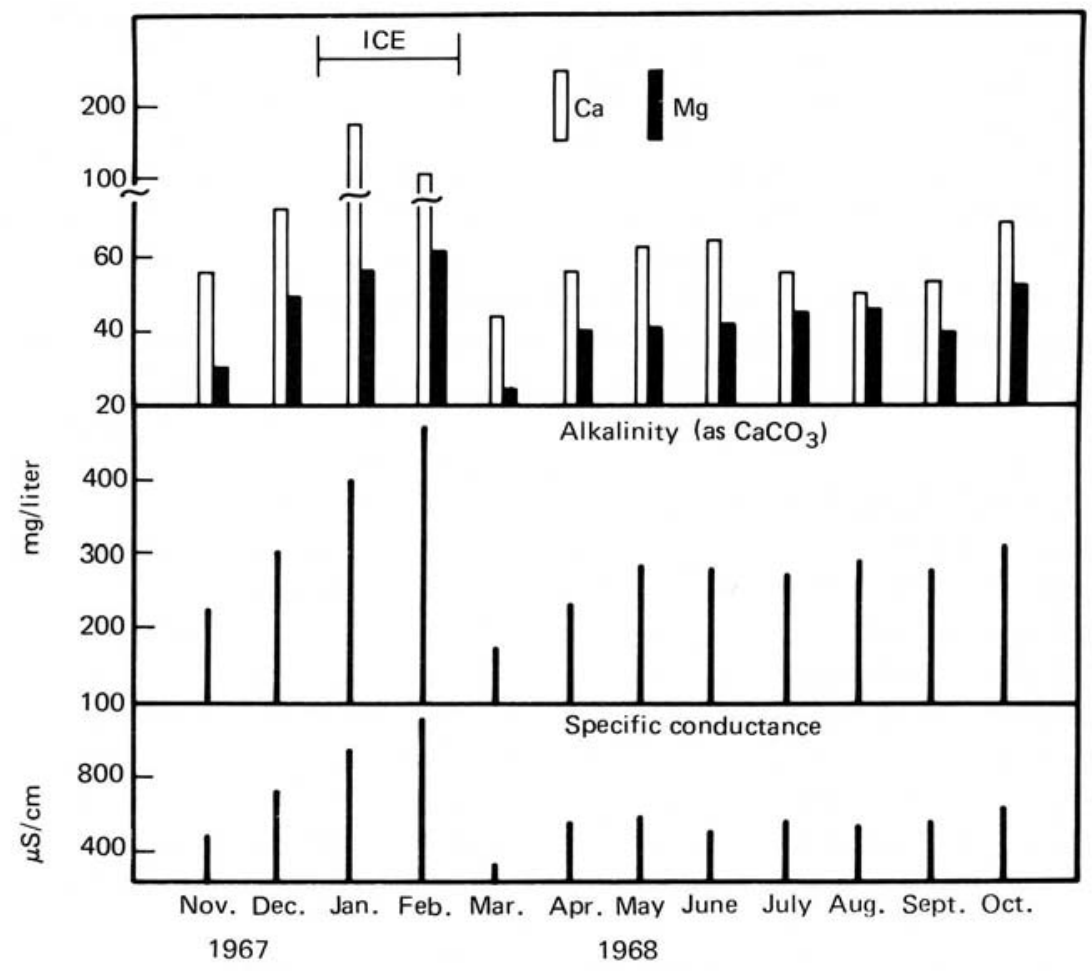

Fig. 4. Monthly variations in calcium, magnesium, alkalinity, and conductance at Horicon Marsh discharge, November 1967-October 1968.

dissolved oxygen, with several $\mathrm{mg} /$ liter of dissolved sulfide. Changes in specific conductance, alkalinity, calcium, and magnesium are of the type normally found in hard-water eutrophic lakes during periods of thermal stratification, where the respiration and other metabolic activities of the microorganisms result in depletion of dissolved oxygen, production of sulfide, and a corresponding decrease in $\mathrm{pH}$. The decrease in $\mathrm{pH}$ results in a solubilization of previously precipitated calcium carbonate. Calcium carbonate has incorporated in it significant amounts of magnesium. During the summer periods both Waunakee and Horicon Marshes are precipitating calcium carbonate; during winter some of this is released to water. Although not studied in this investigation, it is reasonable to expect that calcium carbonate precipitation and dissolution should have an effect on several trace elements present within the marsh. During periods of active precipitation, orthophosphate and trace elements should become incorporated into the sediments at a faster rate, owing to coprecipitation phenomena.

The concentrations of ammonia, nitrate, soluble organic nitrogen, soluble orthophosphate, and total phosphorus for the Horicon discharge waters are presented in Fig. 5. Examination of its data shows that during summer the concentrations of nitrate and ammonia were generally less than $0.1 \mathrm{mg} / \mathrm{liter}$ of 


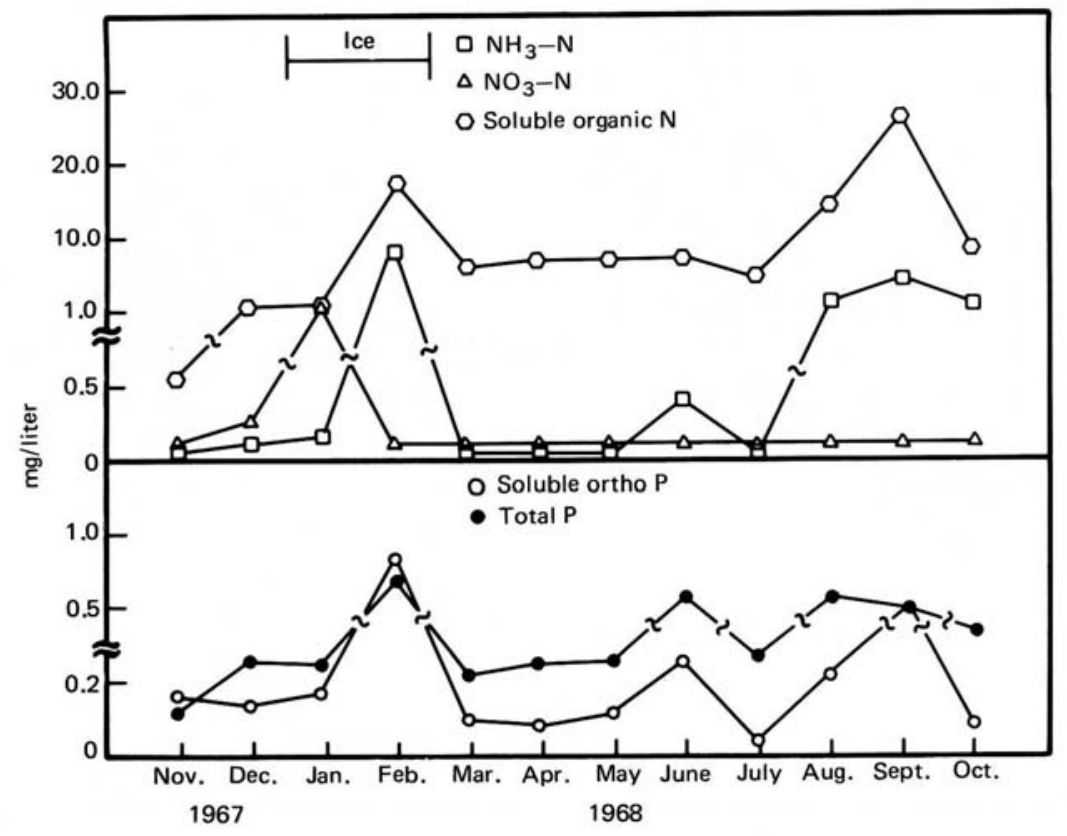

Fig. 5. Monthly variations in $\mathrm{N}$ and $\mathrm{P}$ at Horicon Marsh outlet, Station 7, November 1967-October 1968.

$\mathrm{N}$; during fall and early winter the concentrations were much higher, approaching a total of approximately $1 \mathrm{mg} /$ liter. Typical concentrations for the nitrate and ammonia entering Horicon Marsh from the tributary rivers are approximately 10 $\mathrm{mg} /$ liter of ammonia nitrogen and 1-2 $\mathrm{mg} /$ liter of nitrate nitrogen. Several$\mathrm{mg} /$ liter values are more typical of the concentrations of nitrate found in the groundwaters in the area near Horicon Marsh. The 1-mg/liter values are associated with the ammonia and not the nitrate, and therefore it is expected that throughout the year there is significant denitrification of nitrate occurring within Horicon Marsh. During the growing season the decrease in nitrate is probably associated with the uptake of nitrogen by the aquatic plant community present in the marsh. The organic nitrogen values range from 0.5 up to 20 $\mathrm{mg} /$ liter of $\mathrm{N}$, with the highest concentrations found in early fall of 1968 . These data show the importance of particulate matter as a mode of transport of nitrogen from the marsh.

Phosphorus data presented in Fig. 6 are similar to results obtained from the discharge of Waunakee Marsh, in that soluble orthophosphate and total phosphorus frequently exceed $0.1 \mathrm{mg} /$ liter, even during the active growing season. In general, approximately half of the total phosphorus present in the discharge waters is soluble orthophosphate. A comparison between inlet and discharge waters at Horicon Marsh shows that the waste waters from the various 


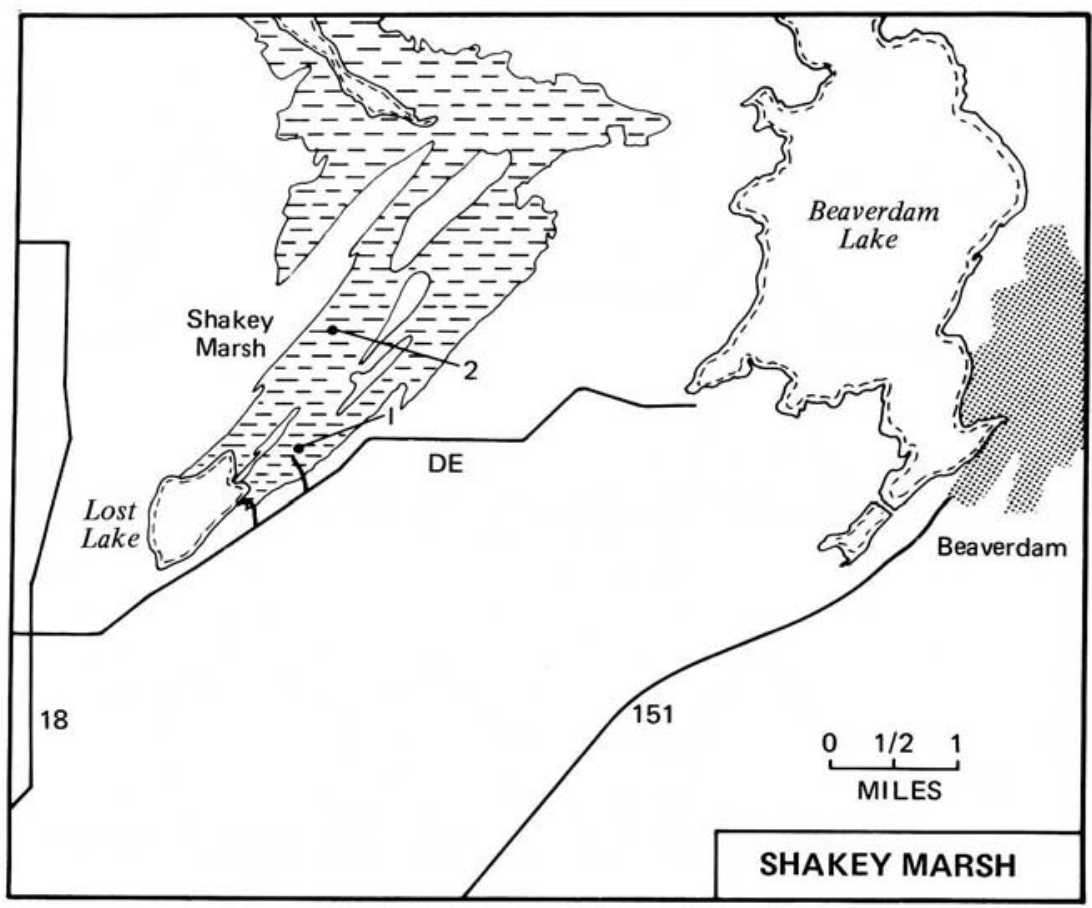

Fig. 6. Shakey Marsh.

municipalities and industries which discharge to the tributary streams of the marsh result in soluble orthophosphate concentrations which are in general much higher than those noted in the discharge waters. In the tributary streams soluble orthophosphate and total phosphorus are in general on the order of 1-3 $\mathrm{mg} /$ liter, which shows that there is a reduction in phosphorus and nitrogen as the water passes through the marsh. However, this reduction is not complete at any time during the year, especially for phosphorus. The phosphorus concentrations found in the discharge waters of Horicon Marsh often exceed by a factor of 10 the typical concentrations found for the growth of excessive amounts of algae in lakes located in south-central Wisconsin $(0.01 \mathrm{mg} / \mathrm{liter}$ of P).

Nutrient Transport from Marshes. Stream gauging stations were established on the outlets of Waunakee and Horicon marshes. These gauges, coupled with the concentration data, enable an estimate to be made of the total flux of nutrients from the marsh. Typical data on the transport of nutrients from Waunakee Marsh in Table 2 clearly show the importance of flow in determining the total transport of various nitrogen and phosphorus compounds from the Waunakee Marsh. The highest flow, on June 27, 1968, of $0.943 \mathrm{~m}^{3} / \mathrm{sec}$, and also the high flows on July 2-3 of 0.486 and $0.329 \mathrm{~m}^{3} / \mathrm{sec}$, transported the largest amount of soluble orthophosphorus and total phosphorus, as well as soluble organic nitrogen, during the study period. These results point to the importance of a 
few days of high flow as a means of transporting nutrients from a marsh, even during the growing season. It is also interesting to note that based on these data, approximately half of the total phosphorus is soluble orthophosphate and the dominant soluble form of nitrogen in the marsh discharge is soluble organic nitrogen. Similar patterns were noted for the discharge from the Horicon Marsh, where increased flows during the month of June of this year resulted in the transport of large quantities of aquatic plant nutrients which were readily available for algal growth.

\section{Discussion of Water Quality}

The data presented above on the discharge characteristics from Waunakee and Horicon marshes, as well as the other data that were obtained in this study, can yield some general conclusions to be drawn about the beneficial and adverse effects of the existing marshes of the type studied on water quality.

Beneficial Effects of Marshes. The beneficial effects of marshes on water quality are primarily associated with storage of aquatic-plant nutrients within the marsh, the transformation of certain forms of chemicals in the marsh system to forms that have a less-deleterious effect on water quality. Probably the most important transformation that can influence the amount of aquatic-plant nutrients discharged from a marsh is the denitrification reaction that occurs within the marsh. In both Horicon and Waunakee marshes, the data presented show that there was significant denitrification of the nitrate that entered the marsh from both groundwater and surface-water inputs, as well as any direct precipitation on the surface of the marsh. Denitrification reactions of this type only occur to a significant extent when very low or zero oxygen concentrations are present. Previous studies by Brezonik and Lee (1966) have shown that denitrification does not occur to a significant extent whenever large amounts of oxygen are present in the sample.

Under anaerobic conditions, the introduction of nitrate to the sample prevented further formation of methane. Methane-producing bacteria were not killed from the nitrate but simply inhibited. As soon as the nitrate had been denitrified to nitrogen gas, methane formation commenced. The possibility of degradation of certain types of compounds that are normally stable under aerobic conditions is one of the additional benefits that can be derived from a marsh.

The marsh environment provides during the growing season for the precipitation of calcium, magnesium, and alkalinity, owing to the precipitation of calcium carbonate in hard-water areas. The magnesium appears to be coprecipitated with the calcium and does not represent a magnesium carbonate formation. As mentioned above, coincident with calcium carbonate precipitation should be the removal of other chemicals, such as phosphate, from the water, and therefore precipitation reactions of this type would be considered beneficial to water quality. 
Table 2. Estimate of Nutrients in Waunakee Discharge Waters on Dates Indicated

\begin{tabular}{lcccccc}
\hline & & \multicolumn{5}{c}{ Total Kilograms/Day } \\
\cline { 3 - 7 } Date & $\begin{array}{c}\text { Flow } \\
\left(\mathrm{m}^{3} / \mathrm{sec}\right)\end{array}$ & $\mathrm{NO}_{3}{ }^{-} \mathrm{N}^{\mathrm{a}}$ & $\mathrm{NH}_{3}$ - N & $\begin{array}{c}\text { Soluble } \\
\text { Organic } \mathrm{N}\end{array}$ & Total P & $\begin{array}{c}\text { Soluble } \\
\text { Ortho P }\end{array}$ \\
\hline $4-26-68$ & 0.271 & 2.32 & 0 & 74.6 & 1.86 & 1.2 \\
$4-28-68$ & 0.121 & 1.05 & 0 & 26.95 & 0.95 & 0.64 \\
$4-29-68$ & 0.121 & 1.05 & 0 & 24.9 & 0.95 & 0.5 \\
$4-30-68$ & 0.138 & 1.2 & 0 & 36.8 & 1.77 & 0.73 \\
$5-1-68$ & 0.111 & 0.955 & 0 & 30.7 & 1.14 & 0.7 \\
$5-2-68$ & 0.111 & 0.955 & 0 & 26.9 & 1.14 & 0.77 \\
$5-3-68$ & 0.111 & 0.955 & 0 & 23.0 & 1.23 & 0.5 \\
$5-4-68$ & 0.107 & 0.91 & 0 & 20.2 & 1.1 & 0.73 \\
$5-5-68$ & 0.107 & 0.91 & 0 & 34.9 & 1.1 & 0.86 \\
$5-27-68$ & 0.055 & 0.455 & 0 & 31.7 & 0.86 & 0.73 \\
$6-18-68$ & 0.003 & 0.023 & 0 & 0.86 & 0.18 & 0.14 \\
$6-27-68$ & 0.943 & 8.1 & 0 & 542.7 & 14.6 & 12.1 \\
$7-2-68$ & 0.486 & 4.2 & 0 & 62.6 & 15.9 & 5.9 \\
$7-3-68$ & 0.329 & 2.8 & 0 & 53.6 & 9.05 & 1.7 \\
$7-5-68$ & 0.160 & 1.4 & 0 & 20.6 & 3.0 & 1.23 \\
$7-12-68$ & 0.003 & 0.023 & 0 & 1.14 & 0.045 & 0.0 \\
$8-5-68$ & 0.003 & 0.023 & 0.22 & 1.45 & 0.045 & 0.23 \\
$9-30-68$ & 0.003 & 0.023 & 0.19 & 1.0 & 0.045 & - \\
\hline
\end{tabular}

a All $\mathrm{NO}_{3}{ }^{-}-\mathrm{N}$ concentrations measured were below the detectable limit $(<0.10 \mathrm{mg} /$ liter $)$. Estimates of $\mathrm{NO}_{3}{ }^{-}-\mathrm{N}$ discharged were based on $0.1 \mathrm{mg} /$ liter of $\mathrm{NO}_{3}{ }^{-}-\mathrm{N}$ and represent maximum values.

The hydrology of a marsh is such that it tends to trap sediments from its watershed, thereby removing from the discharge water large amounts of particulate matter that would normally have an adverse effect on water quality. In addition to the physical filling of the slackwater areas in a stream and lake, this particulate matter would be or is a potential source of nutrients and other chemicals that can be detrimental to water quality.

In addition to trapping sediments, the marsh, particularly during the growing season, tends to reduce the fluctuation of the flow of a stream as a result of the storage capacity and resistance that the water encounters trying to go through the marsh during a period of high flow due to heavy rain. This leveling of flow would tend to minimize the amounts of erosion on downstream banks and therefore would be considered a beneficial effect of marshes on water quality.

Probably one of the greatest benefits that could be derived from a marsh is its effect on the flux of nutrients: e.g., nitrate is largely removed from the input water as a result of denitrification. Phosphorus appears to approximate a steady state each year; however, the input-release pattern is altered by the marsh. Nutrients that enter the marsh during the growing season generally are removed to lower levels than found in the input waters. However, in the spring and fall a substantial part, if not all, of the previously contributed readily available phosphorus, such as orthophosphate, is flushed from the marsh in the 
discharge waters. Some will be incorporated into the sediments; however, probably little is lost by this route unless a marsh has a very high sediment input from its surrounding watershed. Even with active photosynthesis in the Horicon and Waunakee marshes, the soluble orthophosphate concentration in the discharge waters was considerably above the typically cited $10 \mu \mathrm{g} /$ liter of $\mathrm{P}$ levels that have been found for excessive growth of algae in waters in southcentral Wisconsin. Therefore, the marsh is not, even during growing season, a complete barrier to the transport of aquatic plant nutrients. Many marshes have rather well-defined channels of flow which convey a substantial part of the water through the marsh without its interaction with the aquatic-plant communities present therein.

This summer-fall storage-spring release pattern for aquatic plant nutrients is of benefit from two points of view. The first of these is that it does tend to minimize summer algal bloom in lakes that receive drainage from marshes. In some lakes the algae that developed in them is almost exclusively dependent on the transport of nutrients from the watershed and through the thermocline. A marsh on a tributary stream to a lake of this type would tend to cut down the amount of nutrients that the lake receives during the summer period and thereby minimize the late summer algal bloom. The second benefit that can be derived from the alteration of the input-output pattern for nutrients in the marsh is the fact that in a sense the marsh acts as a sponge, soaking up the nutrients throughout the growing season and releasing them all at once in the spring or during periods of high flow. It may be possible to impound the waters from marshes during these periods of high flow and treat them to remove the nutrients present. For example, under certain instances the use of alum as a means for removing phosphorus from natural waters has been shown to be effective at a few hundred $\mathrm{mg} /$ liter. Therefore, if the discharge waters from the marsh could be treated with alum and allowed to stand for relatively short periods of time, the phosphorus would be taken to the sediments. This water could be released and the impoundment created for the storage of the water could be drained with the phosphorus that accumulated in the sediments removed or used for agricultural purposes. Potential for treatment for the spring discharge water to eliminate nutrients merits further study.

Adverse Effects. The data show significant denitrification reactions occurring within the marsh, which would result in taking readily available forms of nitrogen and converting them to nitrogen gas. Recent studies (Lonergan, 1973) have shown that the opposite reaction, nitrogen fixation, occurs within the marsh at a significant rate. This nitrogen would, in part, be found in the discharge waters in the form of organic nitrogen or ammonia. The organic nitrogen would be readily mineralized to form ammonia.

Another problem that can be associated with marshes which could be of significant deleterious effect on water quality is the possibility of production of tastes and odors within the marsh. The marsh environment provides the opportunity for large growths of epiphytes, periphytes, and other attached organisms. Some of these, such as the blue-green algae and certain forms of bacteria, are known to form certain tastes and odors in waters. Some water 
plants frequently experience severe taste and odor problems in their water supply when marshy lands drain into their water supply.

Intense photosynthetic activity makes most marshes discharge areas for organic matter. In the marshes studied in this investigation the high organicmatter content is manifest in the color and COD values. Indirectly the low dissolved-oxygen values present in the discharge waters also represent an indication of the large amounts of organics released. This organic matter can have several significant deleterious effects on water quality. Many water plants that use streams, or impoundments that have large amounts of marshy area in their watershed, experience problems with excessive color in their water during certain times of the year. In some instances this color is very difficult to remove by water-treatment processes; that is, it does not flocculate readily. Associated with this high color in some waters is a marked increase in the amount of iron present in the water, which in itself can cause deterioration in water quality for use in domestic or industrial supplies. This iron appears to be peptized by the organic matter, and possibly some of it is associated in the true complex between the iron and the organics. In addition to interacting with iron, the organic matter present in natural waters could interact with other trace metals that would have a detrimental effect on water quality. Special consideration must be given to the transition metals, such as copper, zinc, and cadmium.

There is a tendency in the limnological literature to directly equate color to total organic matter. Hall (1970) and others have shown that the majority of the organics present in most natural waters are noncolored and that the color is only manifested by a small group. Most of the literature on the characteristics of natural water color is in reality describing the characteristics of the organic matter present in the water. Hall considers the controversy in the aquatic sciences with regard to the colloidal versus dissolved nature of natural colors to have been resolved based on the presence or absence of iron in the sample. With large amounts of iron color is in a colloidal form and can be removed by highspeed centrifugation; in waters with low iron most color appears to be in true solution.

In addition to causing problems in water treatment by production of color, the high organic content of marsh discharge waters can have a detrimental effect by increasing the chlorine demand of the water because of the interactions of chlorine with natural organics. Peterson (1967) has shown that the natural organic matter present in natural waters does compete effectively with other pollutional organics for the sorption sites on activated carbon, so that the use of activated carbon in water and waste-water treatment has to be increased to effectively remove the pollution organics in the presence of large amounts of natural organic matter. The effect of organic matter on water quality in the chemistry of natural waters has been reviewed by Lee and Hoadley (1967).

The intensity of photosynthesis and respiration within the two marshes studied raises some questions about the suitability of these marshes as a fish habitat. The low dissolved-oxygen values found in the discharge waters from Waunakee Marsh at certain times in the summer, and the low dissolved oxygenhigh sulfide present in the discharge from Horicon Marsh indicate that 
these waters would not be suitable fish habitats, except possibly for certain forms of carp. The fact that Waunakee Marsh outlet was completely frozen during January and February of the study period further indicates the limited value of this marsh as a fish habitat. Possibly the long-term area within the marsh that could maintain any type of fish population consists of discharge areas of springs. During summer and winter both marshes studied would not be suitable fish habitats, but this does not preclude the possibility of the fish using this area for spawning in the spring high-flow periods, when water quality is high. However, it would be essential for the small fish to leave the area or stay in an area of intense spring discharge shortly after spawning in order that they are not harmed by the poor water quality in the marsh.

Release of Plant Nutrients from Drained Marshes. The effect of drainage of a marsh on water quality was investigated for Shakey Marsh (See Fig. 6), located near Randolph, Wisconsin. The study included samples of water from the tile field as well as soil samples from recently drained areas and farmed areas in this marsh. For Shakey Marsh soils (Table 3) total phosphorus is approximately 1 $\mathrm{mg} / \mathrm{g}$ of dry soil, with a total carbon near $370 \mathrm{mg} / \mathrm{g}$ and total nitrogen on the order of $30 \mathrm{mg} / \mathrm{g}$. Organic matter is from 74 to 90 percent, depending on the location, which is very high compared to most lake sediments. This demonstrates that this marsh received very little in the way of erosional materials from its watershed and also that there was poor decomposition of the organic residues of the aquatic-plant community that develops within the marsh. The studies on the composition of the tile drainage water from an area of Shakey Marsh that was farmed showed that there was an average nitrate of 0.95 $\mathrm{mg} /$ liter of $\mathrm{N}$, ammonia of $16.9 \mathrm{mg} /$ liter of $\mathrm{N}$, and organic nitrogen of 23.3 $\mathrm{mg} /$ liter of $\mathrm{N}$. The drained but unfarmed area of the marsh had an average composition that was 56, 57, and 60 percent less for these compounds, respecttively, than the farmed area. Very little nitrification was occurring in the period from the release of the material from soil particles until its collection from the drained field.

The total soluble orthophosphate averaged 0.95 and $0.79 \mathrm{mg} /$ liter of $\mathrm{P}$ from

Table 3. Analysis of Shakey Marsh Sediments

\begin{tabular}{|c|c|c|}
\hline Analysis $^{\mathrm{a}}$ & $\mathrm{SM} \# 1^{\mathrm{b}}$ & $\mathrm{SM} \# 11^{\mathrm{c}}$ \\
\hline Total phosphorus (mg/g) & 1.6 & 1.1 \\
\hline Total carbon $(\mathrm{mg} / \mathrm{g})$ & 370 & 448 \\
\hline Organic matter (\%) & 74 & 90 \\
\hline Manganese (mg/g) & 0.45 & 0.034 \\
\hline Potassium (mg/g) & 5.4 & 2.0 \\
\hline Calcium $(\mathrm{mg} / \mathrm{g})$ & 7.9 & 5.5 \\
\hline Magnesium (mg/g) & 5.8 & 3.6 \\
\hline Iron $(\mathrm{mg} / \mathrm{g})$ & 7.2 & 4.4 \\
\hline Organic nitrogen $(\mathrm{mg}$ of $\mathrm{N} / \mathrm{g}$ ) & 30 & 30 \\
\hline
\end{tabular}

asamples dried at $105^{\circ} \mathrm{C}$ and ground to pass 100 mesh.

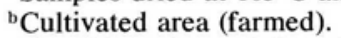

${ }^{\mathrm{c}}$ Uncultivated area (plowed but not farmed). 
the farmed area as compared to 0.12 and $0.08 \mathrm{mg} /$ liter of $\mathrm{P}$ from the unfarmed area (see Chapter 2). Higher concentrations of calcium, magnesium, alkalinity, sodium, sulfate, and potassium were found in the tile drainage water from the farmed part of the marsh. In general, the higher concentrations (see Bentley, 1969) of most elements measured in the farmed versus nonfarmed drainage water appear to be directly related to the use of fertilizers on the farmed part of the marsh. Both areas of the marsh were highly colored (in excess of 70 units) and had a COD generally greater than $50 \mathrm{mg} /$ liter, indicating a large release of organic matter in the drainage water. In general, discharge waters from Shakey Marsh contain very large concentrations of aquatic-plant nutrients ( $\mathrm{N}$ and $\mathrm{P}$ ) and organic matter as well as several other chemical parameters, which would have a detrimental effect on water quality. Further, the fertilizers used on part of this marsh for agriculture contributed to increased chemical discharge, which would cause further deterioration in the quality of the receiving waters for the tile field drainage. The drainage waters from both areas of the marsh would tend to reduce water quality in receiving waters by increasing water hardness, alkalinity, and color and by contributing to the eutrophication of these waters by the discharge of nitrogen and phosphorus.

In order to better define the ultimate amount of nitrogen and phosphorus that might be released from drained marsh soils, two laboratory studies were conducted. Bentley (1969) placed 100-g (dry weight) samples of surface marsh soil in a 20-liter carboy of distilled water and stirred continuously by bubbling compressed air through the suspension. At approximately daily intervals, a sample of the water was withdrawn for soluble nutrient $(0.45 \mu \mathrm{m})$ analyses. Figure 7 presents the data obtained for the unfarmed soils; for the farmed soil the concentration of the nitrogen species was about three times greater than that reported in Fig. 7 for the unfarmed area. The phosphorus data for both leaching experiments were approximately $0.5 \mathrm{mg}$ of soluble orthophosphate per liter as P. The ammonia for the unfarmed soil was approximately $0.1 \mathrm{mg} /$ liter of N. Both soluble organic nitrogen and nitrate increased throughout the study period, indicating intense solubilization and mineralization of particulate nitrogen during the experiment. The rate-controlling step appears to be the solubilization of the particulate nitrogen rather than the nitrification reactions involving the conversion of ammonia to nitrate, since the ammonia concentrations always remained low in the solution.

Amundson (1970) also took samples from farmed and unfarmed areas of Shakey Marsh soil at different locations within the drained marsh area to the laboratory for long-term leaching tests. Approximately 500 wet weight (80 percent water) of surface-soil samples were placed in 20 liters of distilled water. The jugs containing the samples were stirred continuously by a magnetic stirrer. Jugs 1, 2, and 3 were continuously aerated with water-saturated, filtered laboratory air. Through jug 4 was passed a continuous supply of oxygen-free water-saturated nitrogen gas in order to maintain anaerobic conditions in the test. A boric acid trap was placed on the gas outlet of each jug to trap any ammonia that might have been stripped during the course of the leaching period. Before the daily sampling of each jug, the stirrers were stopped, and the 


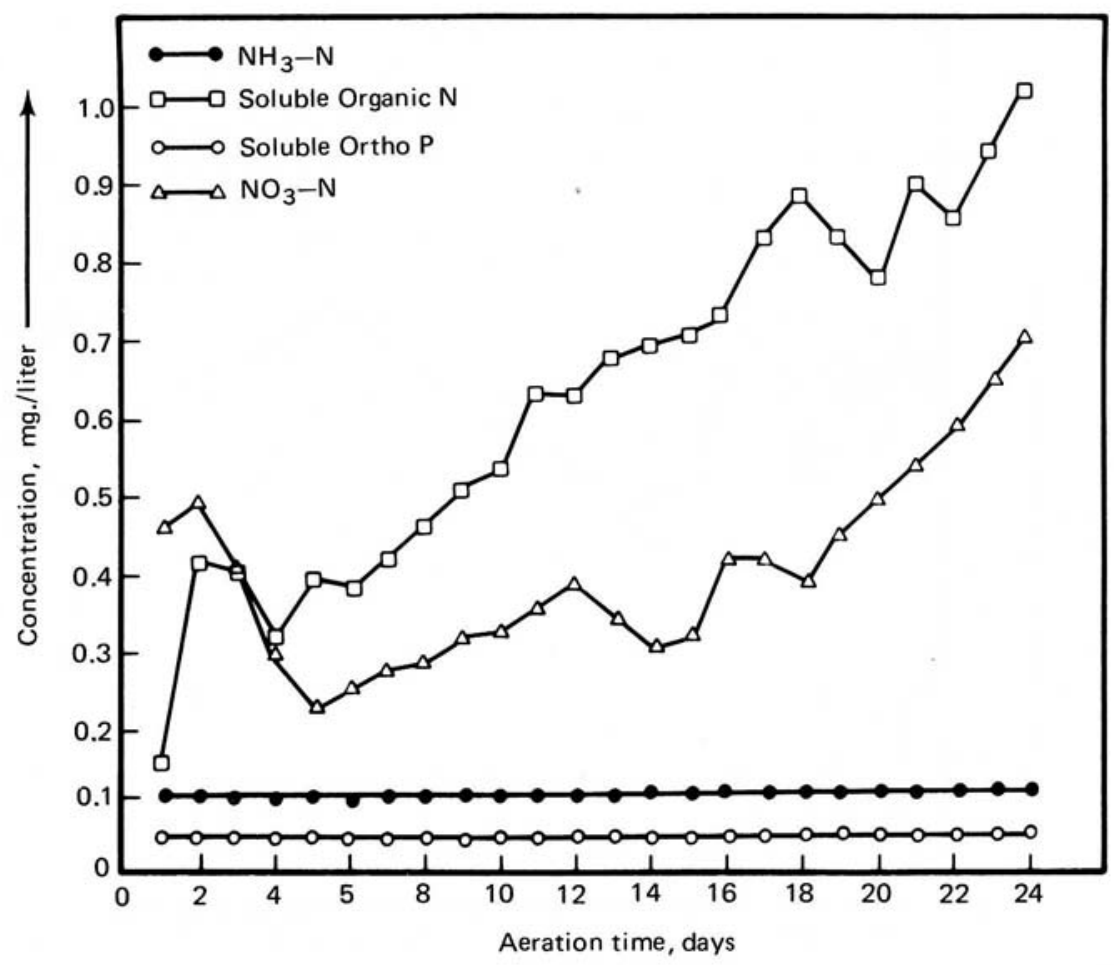

Fig. 7. Release of nutrients from suspension of uncultivated Shakey Marsh soil at room temperature under aerobic conditions, $100 \mathrm{~g}$ dry weight of surface soil used.

suspension was allowed to settle for approximately 45 minutes. Four hundred milliliters of the supernatant was taken for nutrient analysis. To each jug was then added $400 \mathrm{ml}$ of distilled water to keep the total volume approximately the same throughout the test. The samples were immediately filtered through $0.45-\mu \mathrm{m}$ pore-size membrane filters and analyzed for soluble total $\mathrm{P}$, soluble orthophosphate, soluble organic N, soluble ammonia, and nitrate. Figures 8 to 12 present the results of these studies. Each figure is a plot of the cumulative release of the parameter per gram of dry sediment. Jug 1 contains soil samples from the unfarmed area of the marsh, and jugs 2, 3, and 4 contain soil samples from the farmed area, with the same sample being used in jugs 3 and 4 . Figures 8 and 9 present the data obtained from the release of phosphorus from the marsh soils. Jugs 2 and 3 were aerobic, jug 4 was anaerobic. All three jugs showed steady release of phosphorus in both the soluble and total forms during the 50-day leaching period. The initial soluble orthophosphate was about $0.35 \mathrm{mg} / \mathrm{g}$, with initial soluble total phosphorus of $0.6 \mathrm{mg} / \mathrm{g}$ of dry sediment. Jug 1 showed that 22 percent of the total available phosphorus was released on the first day, and this amount increased to well over 60 to 70 percent by the end of the study. 


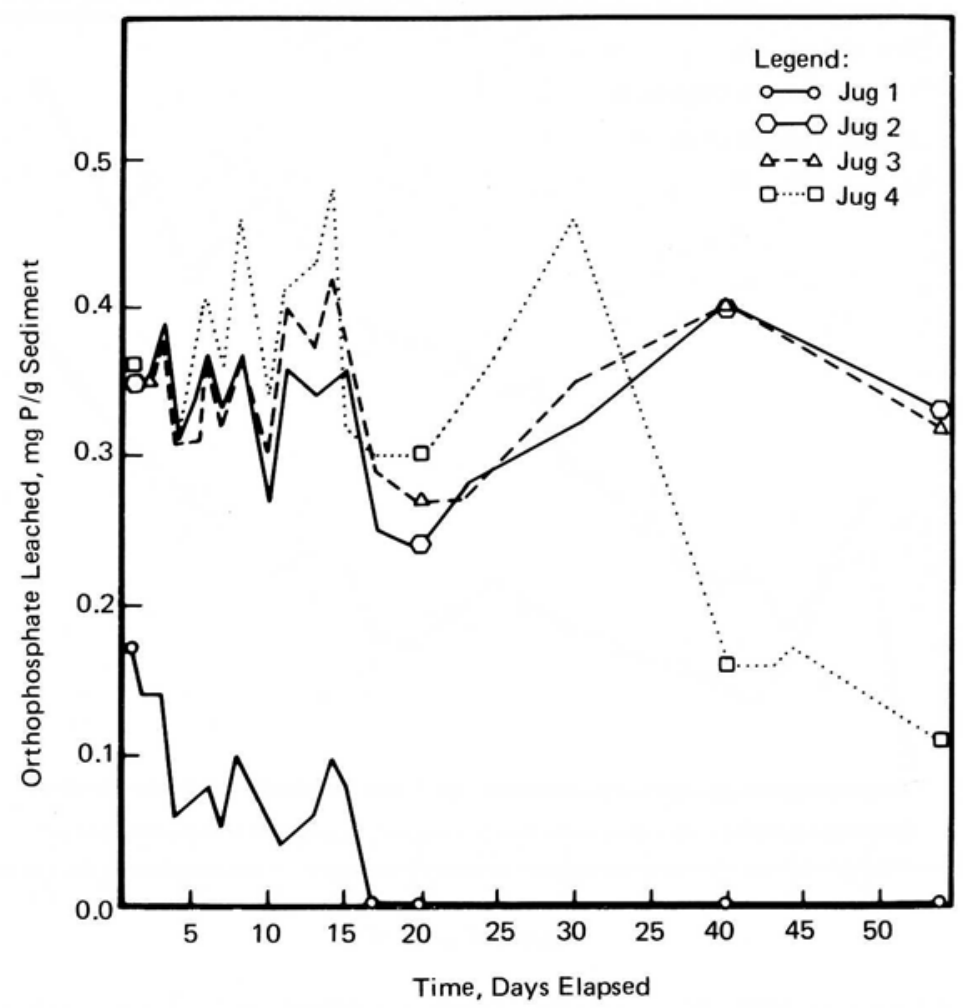

Fig. 8. Orthophosphate release from Shakey Marsh soils.

Only a small part of the total soluble P was measured as soluble orthophosphate. Evidently the predominant reaction occurring in this study was the solubilization of the particulate organic phosphorus to soluble organic phosphorus. It is also possible that some of the soluble total $\mathrm{P}$ was colloidal phosphorus with a diameter of $0.45 \mu \mathrm{m}$ or less. Amundson (1970) has computed, assuming a typical release rate found in this study and a depth of release of 6 inches, that the fertilized farmed part of Shakey Marsh would release about 750 $\mathrm{kg} /$ ha of phosphorus. The nonfarmed fertilized part of the marsh would release about $250 \mathrm{~kg} / \mathrm{ha}$ of phosphorus. The rate of release from both of these areas would be highly dependent on the amount of mixing of the soil and water. The conditions of this study were designed to maximize release rates, since a completely mixed suspension of the sediments was used. Actually the rates in the marsh would be much slower.

The nitrogen-release data are presented in Figs. 10, 11, and 12. Examination shows that the predominant forms of nitrogen released were soluble organic nitrogen and nitrate. Figure 12 shows that by the 50th day of the experiment, almost as much soluble organic nitrogen was released anaerobically in jug 4 as was released in jug 3 under aerobic conditions. As expected, the nitrate in the anaerobic jug (4) was lost, presumably due to denitrification reactions. 


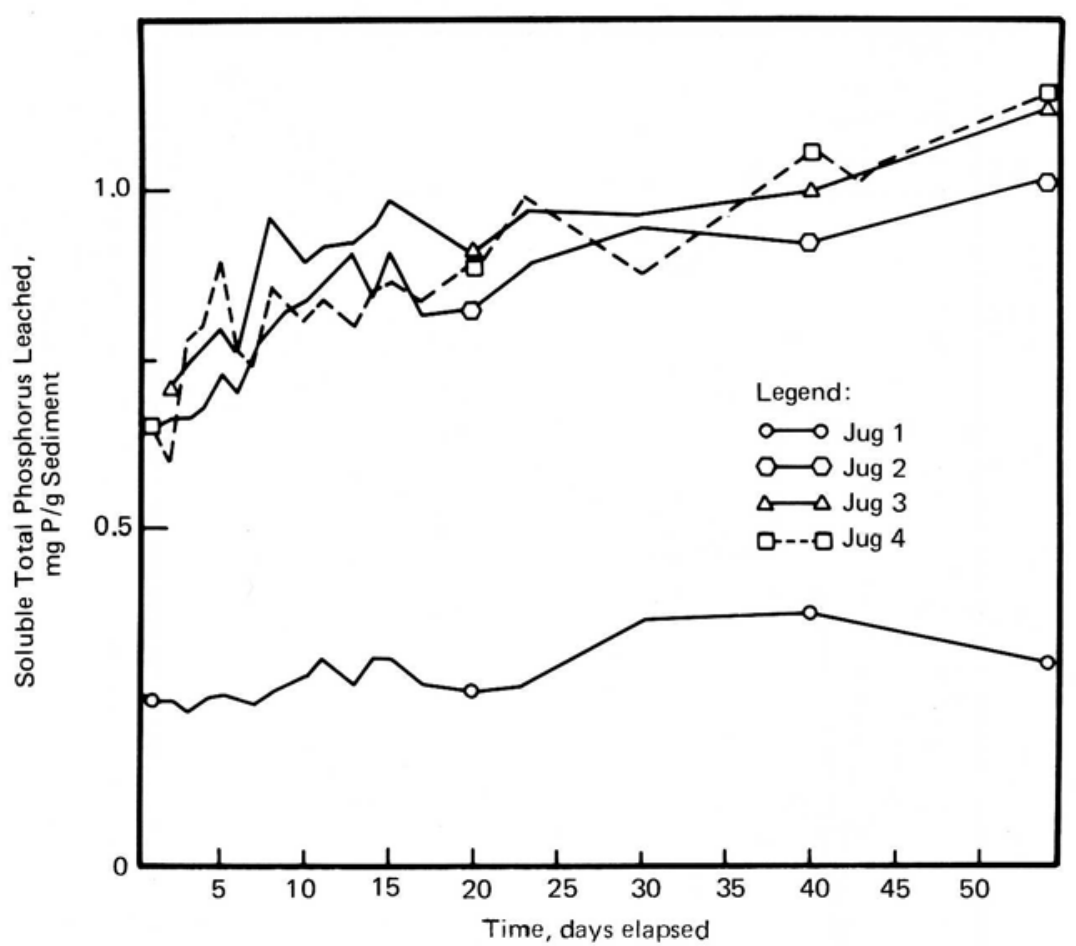

Fig. 9. Total P release from Shakey Marsh soils.

This study confirmed the work of Bentley in that neither study found an accumulation of ammonia during the test. It was, in both situations, rapidly nitrified to nitrate when oxygen was present. Possibly the difference between the results obtained by Bentley on the marsh drainage from the tile field with respect to ammonia and those obtained in the laboratory leaching test is related to the presence of oxygen in the system. Often the dissolved-oxygen values in the tile drainage waters were very low, on the order of $1 \mathrm{mg} /$ liter or so, which may have been sufficiently low to inhibit the growth of large number of nitrifiers in the system. The only significant difference between the two types of soil samples, farmed and unfarmed, was the release of nitrate, where the unfarmed-unfertilized samples released larger quantities of nitrate than did the fertilized part. A computation of the total amount of solubilization of nitrogen compounds that occurred, based on this test over a 50-day period, showed that less than 2 percent of the nitrogen present in the samples was solubilized during this test. On a comparative basis, then, there was a much greater solubilization-mineralization reaction occurring with respect to phosphorus than nitrogen.

Using a similar set of assumptions as for the amounts of phosphorus released per hectare of marsh soil, Amundson (1970) computed that in excess of $450 \mathrm{~kg} / \mathrm{ha}$ of soluble organic nitrogen plus nitrate would be leached from the Shakey Marsh soils. It appears from the data obtained in the studies by Bentley 


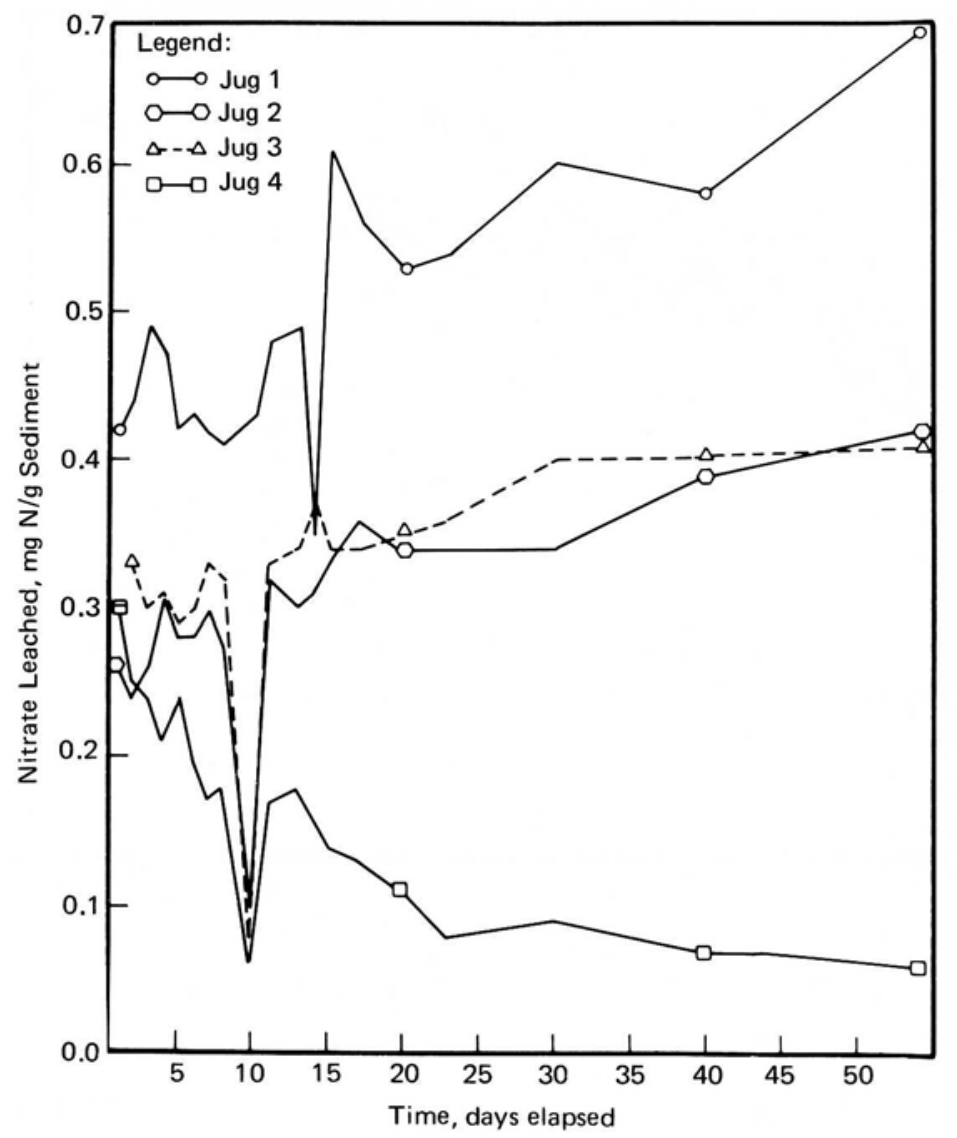

Fig. 10. Nitrate release from Shakey Marsh soils.

(1969) and Amundson (1970) that the primary process responsible for the release of aquatic-plant nutrients from Shakey Marsh soils is the solubilization of particulate organic forms of nitrogen and phosphorus. One of the most interesting results of these studies is the fact that this solubilization process produces large amounts of soluble organic forms of $\mathrm{N}$ and $\mathrm{P}$. This situation is somewhat abnormal for most natural waters since there usually is very little soluble organic nitrogen and phosphorus present in natural water samples that cannot be accounted for by ammonia, nitrite, nitrate, or orthophosphate. Since no effort was made in these studies to determine the specific nature of the compounds that account for the soluble organic nitrogen and phosphorus, it is impossible at this point to determine whether these compounds would be mineralized in natural waters to form soluble orthophosphate, ammonia, and nitrate. From the ammonia data in this study, it appears that this mineralization does occur. However, it is the nitrification reactions that appear to be much faster than the ammonification reactions, leading to a steady-state, low concen- 


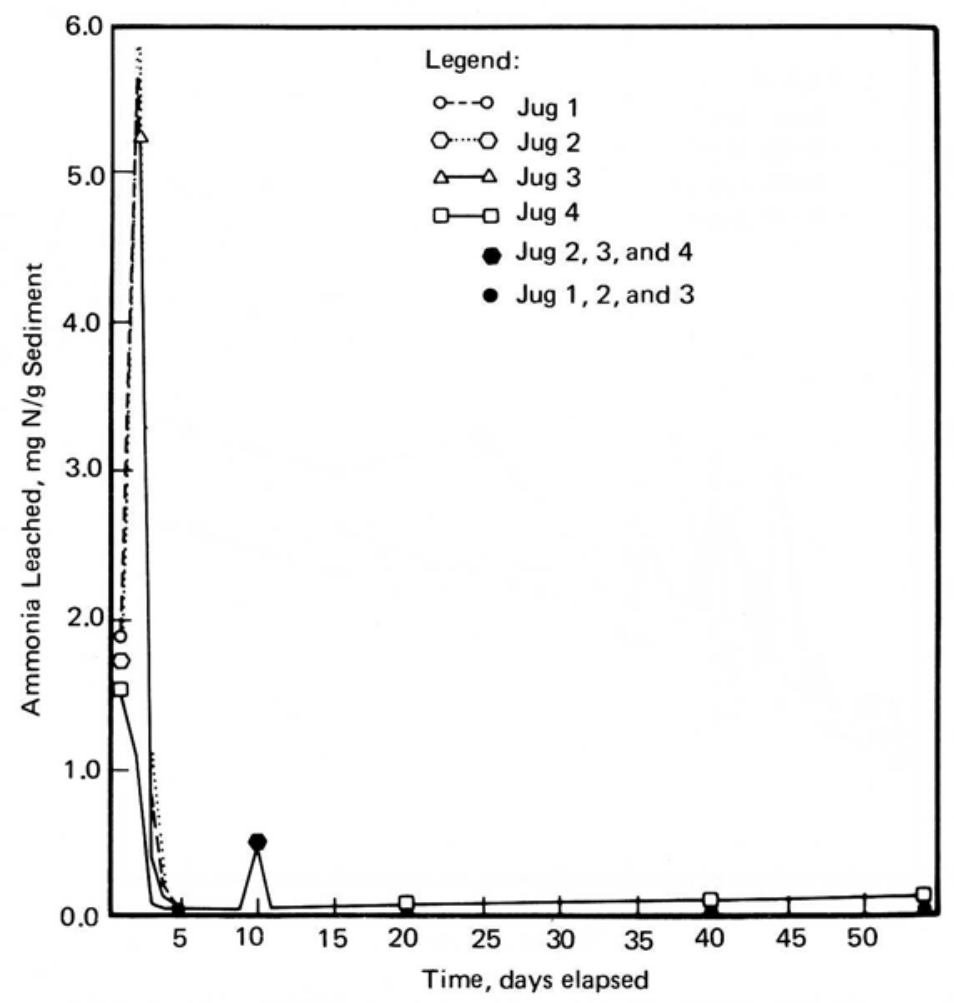

Fig. 11. Ammonia release from Shakey Marsh soils.

tration of ammonia present in the leaching solutions. In addition to the mineralization process, which would convert the soluble organic compounds to forms that are known to be readily available for algal growth, it is conceivable that at least some of these compounds would be directly available in the organic form. There is need for study to characterize these compounds for the rate in which they are converted to ammonia, nitrate, and orthophosphate, and the availability of the organic forms for utilization by algae and macrophytes.

The drainage of a marsh will eliminate all the beneficial effects of the marsh on water quality, as previously cited. In general, the drainage aggravates many of the detrimental effects of the marsh, since there will be increases in color, organics, etc. By far the most significant effect will be an increase in the rates of release of nitrogen and phosphorus compounds. The potential significance of this release may be judged by the fact that typically in central Wisconsin, agricultural lands contribute about $0.5 \mathrm{~kg} / \mathrm{ha} / \mathrm{yr}$ of phosphorus and about the same amount of nitrogen to surface waters via overland flow. An acre of drained marsh may contribute in excess of 50 times this amount in a severalyear period. Therefore, drained marshes of the type studied in this investigation represent significant sources of nitrogen and phosphorus for surface water. 


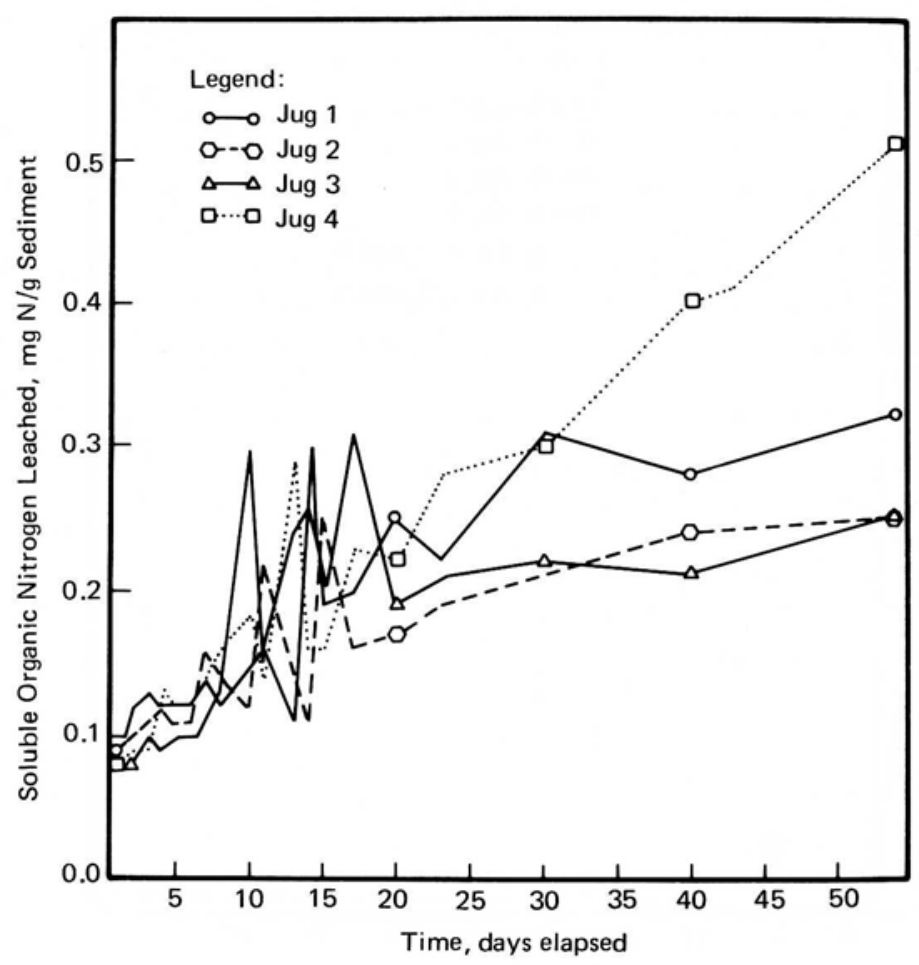

Fig. 12. Soluble organic nitrogen release from Shakey Marsh soils.

\section{Conclusions}

Marshes show both beneficial and detrimental effects on water quality. From an overall point of view, it appears that the beneficial effects outweigh the detrimental effects. The drainage of a marsh for agriculture-urban purposes will cause a significant release of aquatic-plant nutrients, which will accelerate the eutrophication of natural waters that receive this drainage.

\section{Acknowledgments}

This investigation has been principally supported by a contract from the Wisconsin Department of Natural Resources and by Training Grant No. 2T1-WP-22 and Research Fellowship No. 1-F1-WP-26, 189-02, both from the Federal Water Pollution Control Administration. Additional support was received from the U.W. Engineering Experiment Station and the Department of Civil and Environmental Engineering and the University of Texas-Dallas Institute for Environmental Science. 


\section{References}

Amundson, R. W. 1970. Nutrient availability of a marsh soil. M. S. thesis, University of Wisconsin.

Bentley, E. M. 1969. The effect of marshes on water quality. Ph.D. dissertation, University of Wisconsin.

Brezonik, P. L., and G. F. Lee. 1966. Sources of Elemental Nitrogen in Fermentation Gases. J. Air Water Poll. 10:555-560.

Hall, K. J. 1970. Natural organic matter in the aquatic environment. Ph.D. dissertation, University of Wisconsin.

Lee, G. F., and A. F. Hoadley. 1967. Biological activity in relation to the chemical equilibrium composition of natural water. In Equilibrium Concepts in Natural Water System, R. R. Gould, ed., pp. 319-338. (Amer. Chem. Soc. Advan. Chem. Ser. 67.)

Lonergan, D. 1973. Personal communication.

Peterson, J. 0. 1967. Sorption of Rhodamine B on activated carbon, M.S. thesis, University of Wisconsin. 